(c) American Dairy Science Association, 2006.

\title{
Prediction of Nitrogen Excretion in Dairy Farms Located in North Florida: A Comparison of Three Models ${ }^{1}$
}

\author{
V. E. Cabrera, ${ }^{\star 2,3}$ A. de Vries, $†$ and P. E. Hildebrand \\ *School of Natural Resources and Environment, \\ †Department of Animal Sciences, and \\ ‡Department of Food and Resource Economics, University of Florida, Gainesville 32611
}

\section{ABSTRACT}

The increasing $\mathrm{N}$ concentrations in surface and groundwater in north Florida emphasize the need to identify sources of $\mathrm{N}$ loss and ways to reduce them. The amount of $\mathrm{N}$ excretion produced by dairy farms and deposited into the Suwannee River agro-ecosystem is being heavily scrutinized by regulatory agencies because it is believed to contribute significantly to the high $\mathrm{N}$ concentrations in water. Models developed by Van Horn and the USDA-Natural Resource and Conservation Service are used to estimate $\mathrm{N}$ balances on dairy farms. This study explores ways to improve these estimates by using dynamic simulation of $\mathrm{N}$ excretion over time. The Livestock Dynamic North Florida Dairy Farm model ( $\mathrm{LiDyNoFlo),} \mathrm{which} \mathrm{was} \mathrm{created} \mathrm{for} \mathrm{this} \mathrm{purpose,}$ is described. The amount of $\mathrm{N}$ excretion on a dairy farm depends on crude protein in the diet, milk production, the presence of mature bulls and heifers, and seasonality of production. The LiDyNoFlo considered more variables than earlier models, and estimates of $\mathrm{N}$ excretion differed from those of other models. Comparisons consistently showed the LiDyNoFlo predictions of N excretion were between those predicted by the Van Horn model (upper end) and the Natural Resource and Conservation Service model (lower end). The LiDyNoFlo predicted that a 1,000-cow operation produced $324 \mathrm{~kg}$ of $\mathrm{N}$ excretion/d in February and $307 \mathrm{~kg}$ of $\mathrm{N}$ excretion/ $\mathrm{d}$ in August because of seasonal milk production and herd dynamics. Seasonal differences in N excretion are important because they determine the opportunity for $\mathrm{N}$ recycling in the crop fields such that total $\mathrm{N}$ losses into the Suwannee River agro-ecosystem may be minimized.

\footnotetext{
Received July 27, 2005.

Accepted November 17, 2005.

${ }^{1}$ This research was supported by the Florida Agricultural Experiment Station and approved for publication as Journal Series No. R-11060.

${ }^{2}$ Current affiliation: Agricultural Science Center at Clovis, New Mexico State Univ., Clovis 88101.

${ }^{3}$ Corresponding author: vcabrera@ufl.edu
}

Key words: environment, simulation, modeling, nitrogen

\section{INTRODUCTION}

The presence of high concentrations of $\mathrm{N}$ in water is an environmental hazard because it affects human health and ecosystem welfare (Fraisse et al., 1996). The Suwannee River Basin located in north Florida has received much attention since the late 1990s because of increased $\mathrm{N}$ concentrations in water bodies (Pitman et al., 1997; Katz et al., 1999; Albert, 2002). Dairy farms have been identified as an important source of $\mathrm{N}$ in the Suwannee River Basin (Andrew, 1994; Katz and de Han, 1996; Berndt et al., 1998). Therefore, reduction of $\mathrm{N}$ deposition from these dairy farms into the Suwannee River Basin is important.

It is important to estimate accurately the amount of $\mathrm{N}$ excretion produced on dairy farms because it directly impacts their environmental accountability and costs of complying with regulations. It is also important to estimate $\mathrm{N}$ excretion throughout the year because this determines the potential for $\mathrm{N}$ recycling and use by crop fields. It also is important to include $\mathrm{N}$ excreted by young stock and mature bulls because they are part of many dairy farm production systems (Cabrera, 2004). About $24 \%$ of the dairy farms in north Florida use bulls, varying between 3 and $10 \%$ of the total number of cows. Most of them (80\%) use AI in addition to natural mating (de Vries and Risco, 2005). Also, 57\% of the farmers in north Florida raise $100 \%$ of their heifers, $14 \%$ of them do not keep any heifers, and the rest (29\%) raise some proportion in between. The overall average in the area is $55 \%$ of heifers raised on farm (Cabrera, 2004).

In Florida, 2 models are currently widely used to estimate the $\mathrm{N}$ excreted by dairy cows. One model, proposed in several publications by Van Horn et al. (1991, 1994, 1998, 2001), consists of a nutrient balance method. The Van Horn model estimates the amount of $\mathrm{N}$ excreted by the difference between the quantities of $\mathrm{N}$ consumed and $\mathrm{N}$ utilized in milk production, BW gain, and body maintenance. This relatively simple approach bases its predictions of $\mathrm{N}$ excretion from only 2 
cow categories: milking cows and dry cows. This approach estimates the amount of $\mathrm{N}$ entering the dairy farm as the mass of DM feed consumed multiplied by an average $\mathrm{N}$ content factor, and the amount leaving the dairy farm as the amount of milk produced multiplied by an $\mathrm{N}$ content factor. Differences between feed $\mathrm{N}$ input and milk $\mathrm{N}$ output provide an estimate of excreted N. Van Horn's nutrient balance approach does not account for seasonality of production present on most north Florida dairy farms.

The other model is presented by the USDA-Natural Resources Conservation Service (NRCS) through a spreadsheet called Water Budget and Nutrient Balance for Florida (WATNUTFL Version 2.0; Natural Research and Conservation Service, 2001). This model is based on BW of ruminants and standard $\mathrm{N}$ excretion factors. The application created by the NRCS, the WATNUTFL (Natural Research and Conservation Service, 2001), uses standardized estimates of $\mathrm{N}$ excretion based on BW of animals according to the agricultural waste management field handbook (USDA, 1992a, b, c). The NRCS approach disregards the amount of milk production and the seasonality of production on dairy farms in north Florida. This methodology predicts $\mathrm{N}$ excretion by using averages of only 3 cow categories (milking cows, dry cows, and heifers).

Van Horn's nutrient balance model is used widely by dairy farmers and dairy farm consultants in the study area to assist them in the process of obtaining permits. Official agencies, such as the Florida Department of Environmental Protection and NRCS, have the authority to approve or reject these permits. The WATNUTFL is the officially approved engineering software of the NRCS (http://www.fl.nrcs.usda.gov/technical/ program.html) and is to be used in the design of waste storage facilities, in the development of nutrient management budgets, and in the certification of conservation practices by dairy farmers in Florida. Consequently, the WATNUTFL has official consequences in the process of authorizing dairy farm permits in Florida.

Seasonality of cow performance and herd dynamics affects $\mathrm{N}$ excretion. Reproductive efficiency and milk production are typically greater during cooler seasons of the year (West et al., 2003; de Vries, 2004). Excretion of $\mathrm{N}$ is directly impacted by the amount of milk production because milk production drives feed intake and, therefore, $\mathrm{N}$ intake and excretion (Jonker et al., 2002; Nennich et al., 2003). Consequently, a much greater rate of $\mathrm{N}$ excretion is expected during winter months, not only because milking cows are producing more milk, but also because more cows are near their peak milk production. Excretion of $\mathrm{N}$ produced in mid spring would have more opportunity to be used by rapidly growing crops than that produced in winter when less $\mathrm{N}$ is used by crops. Our study describes the creation of a total $\mathrm{N}$ excretion model by expanding previous approaches. The model presented here is a more refined model that accounts for seasonal cow flows, seasonal pregnancy rates, seasonal culling probabilities, and seasonal milk production to predict $\mathrm{N}$ excretion.

The objectives of the present study were 1) to develop a model that accurately predicts monthly $\mathrm{N}$ excretion for dairy farm operations and 2) to compare the new model with 2 existing models that are widely used for dairy farms located in north Florida.

\section{MATERIALS AND METHODS}

\section{Development of the Livestock Dynamic North Florida Model}

General Characteristics. The Livestock Dynamic North Florida model (LiDyNoFlo) is a dynamic, probabilistic Markov-chain simulation model of a herd of cows that estimates the $\mathrm{N}$ excretion on a whole farm. The LiDyNoFlo first simulates the herd over time and then, from the herd dynamics, derives total herd $\mathrm{N}$ excretion. The default inputs for milk production, culling, and pregnancy rates are based on historical data for Florida (de Vries, 2004). These rates can be adjusted, however, for any dairy farm by inputting user-defined data. The model starts in September following north Florida dairy farm practices and simulates $\mathrm{N}$ excretion in monthly steps for as many years as desired.

Details concerning the most relevant variables used to estimate $\mathrm{N}$ excretion are discussed in the following sections.

Cow Flow. The LiDyNoFlo simulates cow flow over time $\left(C_{i, j, k}\right)$ through Markov chains similar to St-Pierre and Jones (2001) and Jalvingh et al. (1994). Animals are assigned to homogeneous production states in 3-D arrays with coordinates determined by months in milk for cows or age after birth for heifers $(i)$, month of pregnancy $(j)$, and lactation number $(k)$. The number of potential states is estimated by the product of the individual states: ( $i=1$ to $32 ; 1$ to 20 for cows and 1 to 32 for heifers $) \times(j=0$ to $9 ; 0$ for nonpregnant cows $) \times(k=0$ to 9 ; 0 for heifers $)=3,200$. Some nonpossible combinations are excluded; for example, a group of cows cannot be 4 mo in milk and 6 mo pregnant. The variables $X_{i, m, k}$ and $Y_{i, m, k}$ represent 3-D matrices that include the monthly probability of survival and pregnancy, respectively, under north Florida dairy farm conditions (Figure $1, \mathrm{~A}, \mathrm{~B}$, and $\mathrm{C}$ ) for cows in a state $i, k, m$, where $m$ is month of the year (1 to 12), starting in September.

In a given month, Equation 1 simulates the number of cows during the second month in milk, whereas Equation 2 represents the number of cows that become preg- 
A
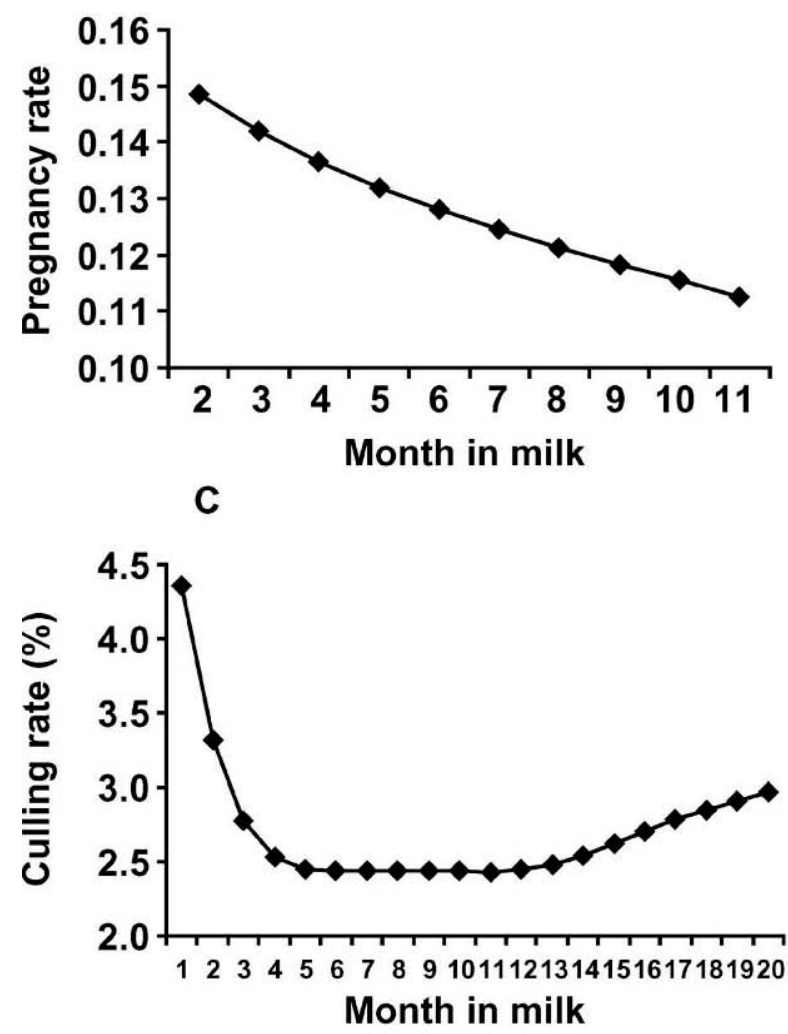

E

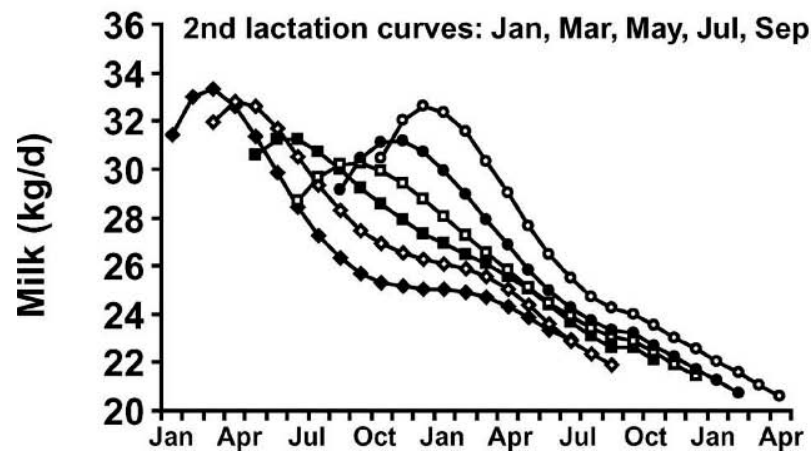

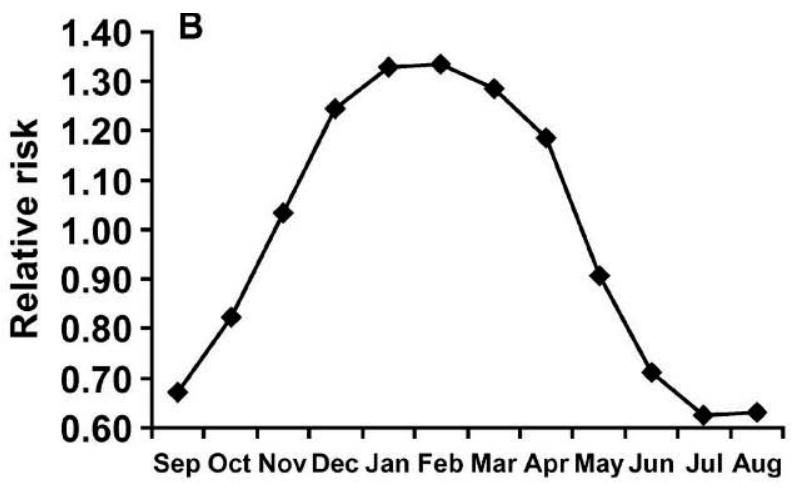

D

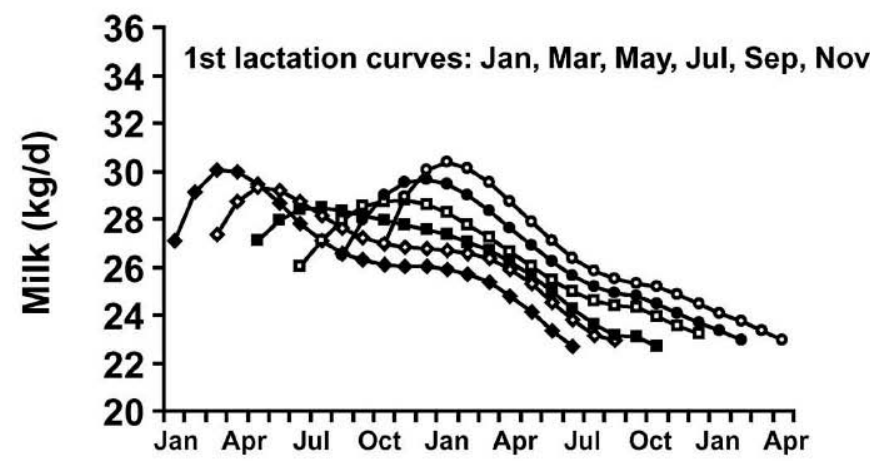

$\mathbf{F}$

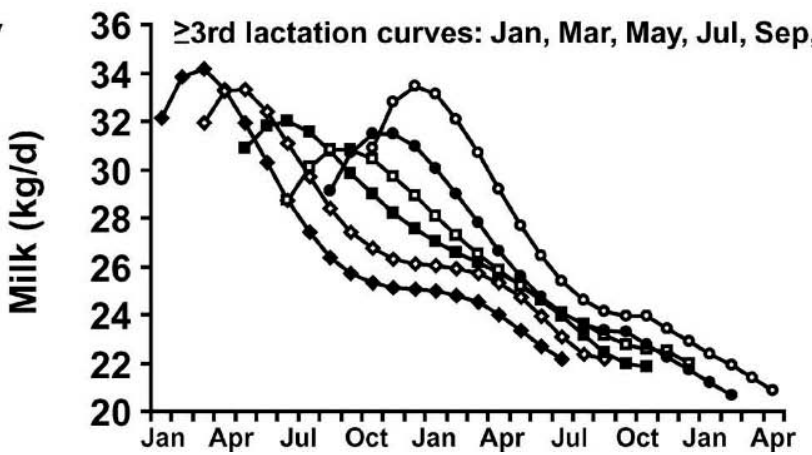

Figure 1. Default inputs in the Livestock Dynamic North Florida Dairy Farm model. Average pregnancy rates by month in milk (A); relative risk of pregnancy rate by month of the year (B); risk of culling by month in milk; and milk production curves by month of calving for lactation 1 (D); 2 (E); and $\geq 3$ (F). Six of 12 curves are shown in panels D, E, and F for easier interpretation. Source: de Vries (2004).

nant. Equation 3 simulates the fraction of cows that remain open or nonpregnant. Equation 4 updates cows that were already pregnant, and Equation 5 represents cows that are calving and beginning the next lactation.

$$
\begin{gathered}
C_{i+1,0, k}=\left(C_{i, 0, k}\right)\left(X_{i, m, k}\right) \text { for } i=1, \\
k=1 \text { to } 9, m=1 \text { to } 12 ; \\
C_{i+1,1, k}=\left(C_{i, 0, k}\right)\left(X_{i, m, k}\right)\left(Y_{i, m, k}\right) \text { for } i=2 \text { to } 12, \\
k=1 \text { to } 9, m=1 \text { to } 12 ;
\end{gathered}
$$

$$
\begin{gathered}
C_{i+1,0, k}=\left(C_{i, 0, k}\right)\left(X_{i, m, k}\right)\left(1-Y_{i, m, k}\right) \text { for } i=2 \text { to } 12, \\
k=1 \text { to } 9, m=1 \text { to } 12 ; \\
C_{i+1, j+1, k}=\left(C_{i, j, k}\right)\left(X_{i, m, k}\right) \text { for } i=2 \text { to } 19, \\
j=1 \text { to } 8, k=1 \text { to } 9, m=1 \text { to } 12 ; \\
C_{1,0, k+1}=\left(\sum_{j=11}^{20}\left(C_{i, 9, k}\right)\left(X_{i, m, k}\right) \text { for } k=0 \text { to } 8,\right. \\
m=1 \text { to } 12 .
\end{gathered}
$$


Heifers start their reproduction program when they are 12 mo old. Therefore, Equation 6, which simulates heifers from 1 to 11 mo of age, does not include a probability of pregnancy. Heifers can become pregnant between 12 and 24 mo (Equation 7) or they can remain open (Equation 8). Equation 9 simulates the aging of pregnant heifers.

$$
\begin{gathered}
C_{i+1,0,0}=\left(C_{i, 0,0}\right)\left(X_{i, m, 0}\right) \text { for } i=1 \text { to } 11, \\
m=1 \text { to } 12 ; \\
C_{i+1,1,0}=\left(C_{i, 0,0}\right)\left(X_{i, m, 0}\right)\left(Y_{i, m, 0}\right) \text { for } i=12 \text { to } 24, \\
m=1 \text { to } 12 ; \\
C_{i+1,0,0}=\left(C_{i, 0,0}\right)\left(X_{i, m, 0}\right)\left(1-Y_{i, m, 0}\right) \text { for } i=12 \text { to } 24, \\
m=1 \text { to } 12 ; \\
C_{i+1, j+1,0}=\left(C_{i, j, 0}\right)\left(X_{i, m, 0}\right) \text { for } i=12 \text { to } 31, \\
j=1 \text { to } 8, m=1 \text { to } 12 .
\end{gathered}
$$

Cows are culled if they are not pregnant after 12 mo in milk. Heifers are culled if they are not pregnant when 24 mo of age.

The number of milking cows is calculated by Equation 10. The number of dry cows is calculated by Equation 11. Cows are assumed to be dry during the last 2 mo of their pregnancy. The number of heifers is assumed to be one-half of all births (Equation 12). Depending on farm management, none, part, or all heifers are kept on the farm. Therefore, the number of heifers is adjusted by the percentage of heifers raised on the farm $(P H R)$.

$$
\begin{gathered}
\text { MILKING }_{\mathrm{m}}= \\
\sum_{k=1}^{9} \sum_{j=0}^{7} \sum_{i=1}^{18} C_{i, j, k, m} \text { for } m=1 \text { to } 12 \\
\mathrm{DRY}_{\mathrm{m}}=\sum_{k=1}^{9} \sum_{j=8}^{9} \sum_{i=1}^{18} C_{i, j, k, m} \text { for } m=1 \text { to } 12
\end{gathered}
$$

$$
\begin{gathered}
\text { HEIFERS }_{\mathrm{m}}= \\
\left(\sum_{j=0}^{9} \sum_{i=1}^{32} C_{i, j, 0}\right)(P H R)+\frac{\left(\sum_{j=11}^{32}\left(C_{i, 9, k}\right)\left(X_{i, m, k}\right)\right)}{2}
\end{gathered}
$$$$
\text { for } \mathrm{k}=1 \text { to } 9, m=1 \text { to } 12 \text {. }
$$

Milk Production. Milk production, $M_{i, m, k}$, is taken from de Vries (2004) and adjusted by adding a constant
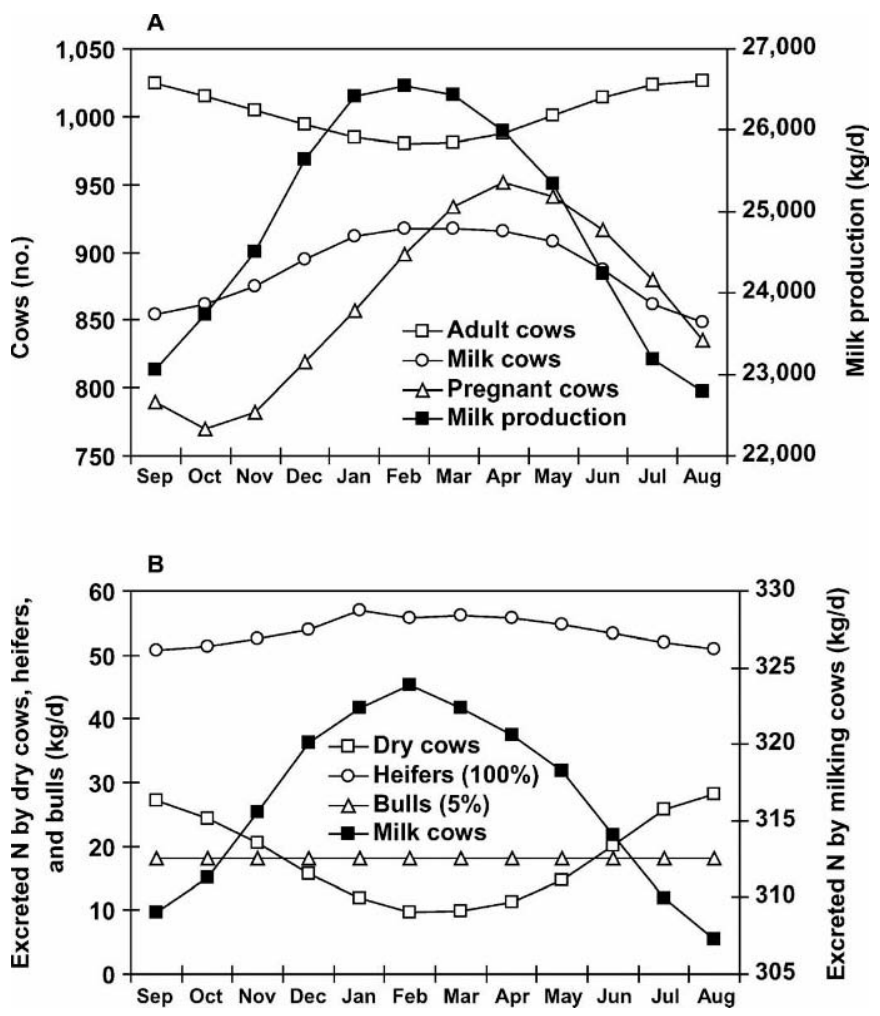

Figure 2. Simulation of a hypothetical 1,000-cow north Florida dairy farm by the Livestock Dynamic North Florida Dairy Farm model. Data shown are milk production and number of animals by month of year for default farm inputs (A) and $\mathrm{N}$ excretion by dry cows, heifers (assuming 100\% of heifers raised), bulls (assuming 1 bull per 20 cows), and milking cows (B).

to match the user-defined rolling herd average (RHA). Figure 2 (D, E, and F) shows these typical lactation curves for Florida based on lactation number, months in milk, and seasonality (de Vries, 2004). Seasonal climatic conditions influence cow flow and milk production because of lesser reproductive efficiency during summer and greater milk production efficiency during winter, which ultimately impact the overall monthly milk production. Some farmers engage management practices to decrease this seasonality. Therefore, any farm can be categorized between $100 \%$ seasonal, when maximum fluctuations are observed, and $0 \%$ seasonal, when seasonal fluctuations are not observed.

Total herd milk production $(\mathrm{kg} / \mathrm{mo})$ is estimated by the milk production in each different cow state, $M_{i, m, k}$, multiplied by the number of cows in that state. This is multiplied by the number of days in each month of the year, $W_{m}$ (Equation 13).

$$
\begin{gathered}
\text { MILK }_{\mathrm{m}}= \\
\left(\sum_{k=1}^{9} \sum_{j=0}^{7} \sum_{i=1}^{18}\left(C_{i, j, k}\right)\left(M_{i, m, k}\right)\right)\left(W_{m}\right) \text { for } m=1 \text { to } 12 .
\end{gathered}
$$


Table 1. Dry matter intake and N excretion by Florida dairy cows based on milk production and low and high (NRC standards) $\mathrm{CP}$ content of $\operatorname{diets}^{1}$

\begin{tabular}{|c|c|c|c|c|c|}
\hline \multirow{2}{*}{$\begin{array}{l}\text { Milk } \\
\text { production }\end{array}$} & \multirow[b]{2}{*}{ DMI } & \multicolumn{2}{|c|}{$\mathrm{CP}$ intake } & \multicolumn{2}{|c|}{$\mathrm{N}$ excretion } \\
\hline & & Low & High & Low CP & High CP \\
\hline & & & $(\mathrm{kg} / \mathrm{d} \mathrm{l}$ & ow) & \\
\hline 45.36 & 25.31 & 3.53 & 3.81 & 0.41 & 0.47 \\
\hline 31.75 & 21.00 & 2.93 & 3.16 & 0.33 & 0.38 \\
\hline 22.68 & 17.78 & 2.48 & 2.67 & 0.27 & 0.32 \\
\hline 0.00 & 11.43 & 1.59 & 1.72 & 0.17 & 0.20 \\
\hline
\end{tabular}

${ }^{1}$ Modified from Van Horn et al. (1998) and USDA (1992a,b).

Excretion of $\boldsymbol{N}$. Excretion of $\mathrm{N}(\mathrm{kg} / \mathrm{mo})$ by different groups of nonmilking animals is based on parameters estimated from book values (Table 4-5; USDA, 1992a and Table FL4-5; USDA, 1992b). Excretion of $\mathrm{N}$ for milking cows is estimated by a third-order polynomial function for milk production parameterized from Table 1 (Equation 14). According to Nennich et al. (2003), milk production drives feed intake and is a better predictor of $\mathrm{N}$ excretion than book standards. For dry cows, excretion of $\mathrm{N}$ is estimated by a constant rate (Equation 15). For heifers, excretion of $\mathrm{N}$ is estimated by a function based on their age (Equation 16). For mature bulls, N excretion is estimated by a constant function multiplied by the number of bulls (TNB; Equation 17).

$$
\begin{gathered}
\mathrm{N}_{\text {milking,m }}= \\
\left(\sum_{k=1}^{9} \sum_{j=0}^{7} \sum_{i=1}^{18}\left(0.17+2.4^{-3}\right)\left(M_{i, m, k}\right)+1^{-4}\left(M_{i, m, k}\right)^{2}\right. \\
\left.-2^{-7}\left(M_{i, m, k}\right)^{3}\left(C_{i, j, k}\right)\left(W_{m}\right)\right) \text { for } m=1 \text { to } 12 ; \\
\mathrm{N}_{\mathrm{dry}, \mathrm{m}}= \\
\left(\sum_{k=1}^{9} \sum_{j=8}^{9} \sum_{i=1}^{18}(0.17)\left(C_{i, j, k}\right)\left(W_{m}\right)\right) \text { for } m=1 \text { to } 12 ; \\
\left(\sum_{j=0}^{9} \sum_{i=1}^{32}\left(2.8^{-2}+i\right)\left(1.2^{-2}\right)\left(C_{i, j, 0}\right)(P H R)\left(W_{m}\right)\right) \\
\text { for } m=1 \text { to } 12 ; \\
\mathrm{N}_{\text {bull,m }}= \\
(0.1651)(T N B)\left(W_{m}\right) \text { for } m=1 \text { to } 12 .
\end{gathered}
$$

Equations 14 and 15, which are parameterized according to Table 1, can be better understood with an example. We can deduce from Table 1 that a dry cow would have $11.4 \mathrm{~kg}$ of $\mathrm{DMI} / \mathrm{d}$ and would excrete 0.17 $\mathrm{kg}$ of N/d. When the cow is producing milk, we can use Equation 14 and Table 1 . When the cow produces 20 $\mathrm{kg}$ of milk/d and DMI is $16.8 \mathrm{~kg} / \mathrm{d}, 0.25 \mathrm{~kg}$ of N/d would be excreted. When a cow produces $30 \mathrm{~kg}$ of milk/d, DMI would be $20.3 \mathrm{~kg} / \mathrm{d}$, and $0.32 \mathrm{~kg}$ of N/d would be excreted. When production is $40 \mathrm{~kg}$ of milk/d with a DMI of $23.7 \mathrm{~kg} / \mathrm{d}$, excretion would be $0.41 \mathrm{~kg}$ of N/d. From data presented in Table 1, greater amounts of milk production would trigger more DMI because of inefficiencies, which leads to a concomitant increase in $\mathrm{N}$ excretion.

Estimates of $\mathrm{N}$ excretion are based on experiments using Holsteins milked $2 \times$ daily, which is predominant in the study area (90\%; Cabrera, 2004) taken from USDA (1992a, b) and Van Horn et al. (1998). Estimated $\mathrm{N}$ excreted by milking and dry cows is additionally adjusted depending on the amount of $\mathrm{CP}$ in the diet. Based on NRC (2001) recommendations, average CP can be categorized as "low," for which the average protein in all rations is $13.9 \%$, or "high," for which the average protein in all rations is $15 \%$. These were used to correct the $\mathrm{N}$ excretion prediction. According to the NRC (2001), N excretion increases $9.6 \%$ for every $1 \%$ increase in $\mathrm{CP}$ in the diet between the low and high ranges. Equations 18 and 19 include those adjustments for milking and dry cows.

$$
\begin{gathered}
\mathrm{N}_{\mathrm{CP} \text {-milking,m }}= \\
\left(\mathrm{N}_{\text {milking, m }}\right)[1+(\mathrm{CP}-13.9370)(0.0956)] \\
\text { for } m=1 \text { to } 12 ; \\
\mathrm{N}_{\mathrm{CP}-\mathrm{dry}, \mathrm{m}}= \\
\left(\mathrm{N}_{\mathrm{dry}, \mathrm{m}}\right)[1+(\mathrm{CP}-13.9370)(0.0956)] \\
\text { for } m=1 \text { to } 12 .
\end{gathered}
$$

We can illustrate Equations 18 and 19 by continuing with the previous example. If the $\mathrm{CP}$ in the diet is $13.9 \%$, all of the predicted $\mathrm{N}$ excretion values for dry cows and lactating cows producing 20,30 , and $40 \mathrm{~kg} / \mathrm{d}$ would be $0.17,0.25,0.32$, and $0.41 \mathrm{~kg} / \mathrm{d}$, respectively. If the amount of $\mathrm{CP}$ is $15 \%$, the predicted $\mathrm{N}$ excretion would increase to $0.20,0.30,0.38$, and $0.49 \mathrm{~kg} / \mathrm{d}$, respectively.

Computer Implementation. The LiDyNoFlo was entirely developed in Microsoft Excel using embedded Visual Basic to produce a user-friendly product for farmers, extension services, and regulatory agencies. 
The LiDyNoFlo runs interactively and presents data and graphic results on the same screen in which it is manipulated and run.

\section{Characteristics of the Van Horn and NRCS Models}

Van Horn Model. The Van Horn model (Van Horn et al., 2001) predicts yearly $\mathrm{N}$ excreted ( $\mathrm{kg}$ of N/yr per herd) by subtracting the amount of $\mathrm{N}$ contained in the milk produced and the $\mathrm{N}$ used in maintenance from the total $\mathrm{N}$ input from the feed (Equations 20 and 21).

$$
\begin{gathered}
\mathrm{N}_{\text {excreted, milking }}=\mathrm{N}_{\text {feed, milking }} \\
-\left(\mathrm{N}_{\text {milk }}+\mathrm{N}_{\text {maintenance, milking }}\right) ; \\
\mathrm{N}_{\text {excreted, dry }}=\mathrm{N}_{\text {feed, dry }}-\mathrm{N}_{\text {maintenance, dry }} .
\end{gathered}
$$

The amount of $\mathrm{N}$ in feed is calculated by multiplying DMI (kg/yr per group) by the percentage of CP and by the percentage of $\mathrm{N}$ in the $\mathrm{CP}$ (Equation 22). The $\mathrm{N}_{\text {milk }}$ $(\mathrm{kg} / \mathrm{yr})$ was calculated as $15.5 \%$ of the milk protein content, which is assumed to be $3.25 \%$ (Equation 23). The $\mathrm{N}$ for maintenance is a constant factor of $0.0012 \mathrm{~kg}$ of $\mathrm{N}$ per cow (Equation 24).

$$
\begin{gathered}
\mathrm{N}_{\text {feed, group }}=\left(\mathrm{DMI}_{\text {group }}\right)\left(\% \mathrm{CP}_{\text {group }}\right)(16 \%) \\
\text { for group = milking, dry; } \\
\mathrm{N}_{\text {milk }}=(\mathrm{MILK})(3.25 \%)(15.5 \%) ; \\
\mathrm{N}_{\text {maintenance }}=0.0012 .
\end{gathered}
$$

Default DMI values are 19.2 and $11.5 \mathrm{~kg} / \mathrm{d}$ per cow for milking and dry cows, respectively. The amount of milk produced and CP are user-defined, whereas all other measures are embedded in the model.

NRCS Model. The USDA-NRCS, WATNUTFL application Version 2.0 (Natural Research and Conservation Service, 2001) predicts yearly $\mathrm{N}$ excretion $(\mathrm{kg} / \mathrm{yr}$ per herd) by multiplying BW of cows by a standard $\mathrm{N}$ excretion factor (Equations 25, 26, and 27).

$$
\begin{gathered}
\mathrm{N}_{\text {excreted, milking }}= \\
\left(\mathrm{WEIGHT}_{\text {milking }}\right)\left(\mathrm{Nex}_{\text {milking, CP }}\right) \text { for } \mathrm{CP}=\text { low, high; } \\
\mathrm{N}_{\text {excreted, dry }}= \\
\left(\mathrm{WEIGHT}_{\mathrm{dry}}\right)\left(\mathrm{Nex}_{\mathrm{dry}, \mathrm{CP}}\right) \text { for } \mathrm{CP}=\text { low, high; } \\
\mathrm{N}_{\text {excreted, heifer }}=\left(\mathrm{WEIGHT}_{\text {heifer }}\right)\left(\mathrm{Nex}_{\text {heifer }}\right)
\end{gathered}
$$

where weight $t_{\text {group }}(\mathrm{kg})$ is the assumed average weight of all animals in a particular category and $\mathrm{Nex}_{\text {group }}$ is the standard book value (USDA, 1992b) of $\mathrm{N}$ excreted by the cow category. For heifers, the $\mathrm{N}$ excretion (Nexheifer) is assumed to be $0.031 \%$ of their BW. The N excretion of milking and dry cows also depends on their protein diet formulation ( $\mathrm{Nex}_{\text {milking, }} \mathrm{CP}$ and $\left.\mathrm{Nex}_{\mathrm{dry}}, \mathrm{CP}\right)$. For low- and high-protein diets, this is 0.04 and $0.05 \%$ for milking cows and 0.03 and $0.03 \%$ for dry cows. The low- and high-protein diets are based on NRC (2001) standards.

\section{Initial Data}

Detailed parameters relative to milk production $\left(M_{i, m, k}\right)$, culling $\left(X_{i, m, k}\right)$, and pregnancy rates $\left(Y_{i, m, k}\right)$ were obtained from de Vries (2004) and are summarized in Figure 1. They were confirmed by a survey of dairy farms performed in north Florida (Cabrera, 2004).

\section{Experiment: LiDyNoFlo Comparison with Van Horn and NRCS Predictions}

A hypothetical 1,000-cow north Florida dairy farm was created using contemporary and local information from a survey (Cabrera, 2004) to compare systematically predicted $\mathrm{N}$ excretion by NRCS and Van Horn models and by LiDyNoFlo. The 3 models were used to calculate overall farm $\mathrm{N}$ excretion under different scenarios of CP, milk RHA, confined time, presence of mature bulls, percentage of heifers raised, seasonality of operation, and weight of cows. Levels of comparison and default values for each one of these factors are summarized in Table 2. All comparisons were performed with respect to the overall farm amount of $\mathrm{N}$ excreted (kg per farm) with the assumption of no losses.

Levels of the factors involved in a comparison were changed one at a time, and default values were held for all of the other factors. A combination of all default levels of factors in Table 2 describes the hypothetical farm: high-CP, RHA $=9,000 \mathrm{~kg}$ of milk, $0 \%$ heifers raised on farm, $0 \%$ mature bulls, $100 \%$ seasonal operation, and $\mathrm{BW}=635 \mathrm{~kg}$ per cow.

\section{RESULTS}

\section{Simulation of Individual Cow States by LiDyNoFlo}

Table 3 presents $\mathrm{N}$ excretion per cow per day using LiDyNoFlo for specific cow states. Excretion of $\mathrm{N}$ is directly impacted by milk production, protein content in diet, and age. Dry cows excrete less $\mathrm{N}$ than lactating cows, an amount slightly greater than those of bulls.

\section{Simulation of the Hypothetical Farm by LiDyNoFlo}

The LiDyNoFlo begins by assigning all 1,000 cows to the same state, $C_{1,0,1}$ (first month in milk, nonpregnant, 
Table 2. Default values and compared levels in a hypothetical 1,000-cow north Florida dairy farm

\begin{tabular}{lcc}
\hline Farm factor & Default & Compared levels \\
\hline CP (\% of DMI) & 15.0 (high) & 13.9 (low); 15.0 (high) \\
Rolling herd average (kg/yr) & 9,000 & $8,000,9,000,10,000$ \\
Percentage of heifers raised (\% of born) & 0 & $0,50,100$ \\
Percentage of mature bulls (\% of total cows) & 0 & $0,5,10$ \\
Seasonality of operation (\%) & 100 & $0,50,100$ \\
BW of cows (kg) & 635 & $550,635,700$ \\
\hline
\end{tabular}

first lactation) and then populating all cow and heifer states. The LiDyNoFlo reaches steady state of cow flow after $132 \mathrm{mo}$. This steady state implies that the average number of cows per year is 1,000 , although small variations in cow numbers exist over time. The model replaces culled cows and sells excess animals to maintain herd size; however, independent seasonal pregnancy $\left(Y_{i, m, k}\right)$ and culling $\left(X_{i, m, k}\right)$ rates, together with a lag time between replacement (heifer) and culled animal (cow), cause small variations. These seasonal changes in cow flow are presented in Figure 2 for a $100 \%$ seasonal farm. Figure 2A shows slight variation in the total number of cows through the year: 980 in February to 1,026 in August for the 1,000-cow herd. Milking cows and pregnant cows had more seasonal variations; both increased in number toward winter and spring months and decreased toward summer and fall months. Number of milking cows reached its peak during February and March (920 cows); more pregnant cows were observed in April (950 cows). In addition to seasonality of milking cow numbers, milk production is also directly impacted by seasonal milk production patterns. Figure $2 \mathrm{~A}$ also shows seasonal milk production for the herd that reached its maximum during February $(26,800 \mathrm{~kg}$ of milk/d) and its minimum in August $(22,790 \mathrm{~kg}$ of milk/d).

Figure 2B presents the N excreted by dry cows, heifers (assuming $100 \%$ of heifers raised), bulls (assuming $5 \%$ of bulls raised), and milking cows. The $\mathrm{N}$ excreted

Table 3. Excretion of $\mathrm{N}$ per cow as predicted by the Livestock Dynamic North Florida Dairy farm model

\begin{tabular}{llllr}
\hline & $\begin{array}{l}\text { Low } \\
\text { Animal category }\end{array}$ & $\begin{array}{l}\text { High } \\
\text { CP }\end{array}$ & $\begin{array}{l}\text { Average } \\
\text { CP }\end{array}$ & DMI \\
\cline { 2 - 5 } & \multicolumn{4}{c}{$(\mathrm{kg} / \mathrm{d}$ per cow) } \\
\cline { 2 - 5 } Lactating at $40 \mathrm{~kg}$ of milk/d & 0.41 & 0.49 & 0.45 & 23.68 \\
Lactating at $30 \mathrm{~kg}$ of milk/d & 0.32 & 0.38 & 0.35 & 20.34 \\
Lactating at $20 \mathrm{~kg}$ of milk/d & 0.25 & 0.30 & 0.28 & 16.83 \\
All lactating cows & 0.33 & 0.39 & 0.36 & 20.28 \\
Dry cows & 0.17 & 0.20 & 0.18 & 11.43 \\
Heifers $(20 \mathrm{mo})$ & NA & NA & 0.12 & 7.62 \\
Heifers $(15 \mathrm{mo})$ & NA & NA & 0.09 & 6.02 \\
Calves (5 mo) & NA & NA & 0.04 & 2.83 \\
Bulls & NA & NA & 0.17 & 11.43 \\
\hline
\end{tabular}

${ }^{1} \mathrm{NA}=$ not applicable. by heifers was substantially greater than the $\mathrm{N}$ excreted by dry cows $(19,590 \mathrm{vs} .6,680 \mathrm{~kg}$ of N/yr). The $\mathrm{N}$ excreted by dry cows had more seasonal variation, and it had an inverse pattern to the $\mathrm{N}$ excreted by heifers because the number of dry cows varied inversely with the number of heifers (Figure 2A). The $\mathrm{N}$ excreted by dry cows had its peak in August $(28 \mathrm{~kg} / \mathrm{d}$ ) and its minimum in February and March $(10 \mathrm{~kg} / \mathrm{d})$. The $\mathrm{N}$ excreted by heifers reached its maximum in January $(57 \mathrm{~kg} / \mathrm{d})$ and its minimum in August and September (51 kg/d). The $\mathrm{N}$ excreted by milking cows alone was substantially greater than the $\mathrm{N}$ excreted by all other combined groups. In February, this was $324 \mathrm{~kg} / \mathrm{d}$ compared with $84 \mathrm{~kg} / \mathrm{d}$ for all other groups; in August, this was 307 $\mathrm{kg} / \mathrm{d}$ compared with $97 \mathrm{~kg} / \mathrm{d}$ for all other groups.

\section{LiDyNoFlo Comparison with NRCS and Van Horn Models}

A major difference and a major consistency among models were noticed in the following comparisons. The major difference and advantage was that only LiDyNoFlo predicted seasonality or monthly variations in $\mathrm{N}$ excreted. The major consistency was that overall predictions from LiDyNoFlo were close and varied similarly with the other 2 models.

Comparisons Regarding $\boldsymbol{C P}$. As expected, N excreted varied in direct relationship with the amount of $\mathrm{CP}$ in the diet. The proportion of this change, however, varied among models. Compared with the default values with high $\mathrm{CP}$, the amount of $\mathrm{N}$ excreted decreased $12.7 \%$ in the Van Horn model, $9.6 \%$ in LiDyNoFlo, and $16.3 \%$ in the NRCS model, when the CP was assumed to be low. The annual totals by the 3 models with high CP were relatively closer $(120.6,116.0$, and 111.5 tonne/ yr) than with low CP (108.8, 105.9, and 95.7 tonne/yr; Figure 3 ). With both CP amounts, LiDyNoFlo estimates were between the predictions of the other 2 models. The Van Horn model predicted the greatest amounts of $\mathrm{N}$ excretion: 330 and $298 \mathrm{~kg} / \mathrm{d}$ for high- and low-protein diets, whereas the NRCS predicted the least amounts: 305 and $262 \mathrm{~kg} / \mathrm{d}$ for high- and low-protein diets, respectively.

The LiDyNoFlo estimates were closer to the Van Horn model with low CP and closer to the NRCS model 

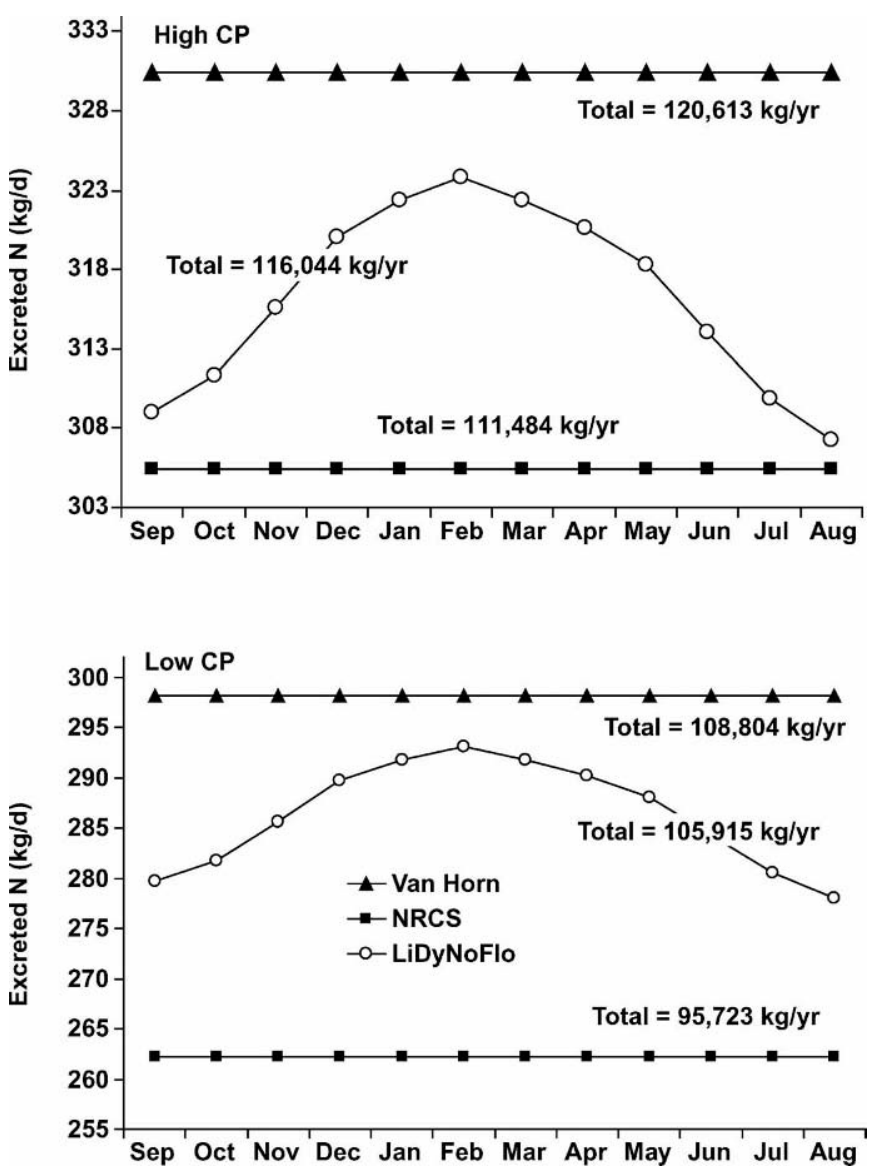

Figure 3. Nitrogen excretion by a hypothetical 1,000-cow dairy farm in north Florida as simulated by different models: Van Horn, Natural Resource and Conservation Service (NRCS), and the Livestock Dynamic North Florida (LiDyNoFlo).

with high CP. The LiDyNoFlo projected that the seasonal variation in $\mathrm{N}$ excretion could represent up to $480 \mathrm{~kg} / \mathrm{mo}$ ( $6 \%$ of change) between the greatest and least months. Less $\mathrm{N}$ excretion was predicted during summer-fall seasons (August was 278 and $307 \mathrm{~kg} / \mathrm{d}$ for low- and high-CP diets, respectively), and greater $\mathrm{N}$ excretion was predicted during winter-spring seasons (February was 293 and $324 \mathrm{~kg} / \mathrm{d}$ for low- and highCP diets, respectively), which is consistent with milk production seasonality. The LiDyNoFlo was 93.0 and 98.2\% of the Van Horn model for August and February for the high-protein diet and was 93.3 and $98.3 \%$ for the same months for the low-protein diet. The LiDyNoFlo was 100.7 and $106.2 \%$ of the NRCS model for August and February for the high-protein diet and 106.1 and $111.8 \%$ for the same months for the lowprotein diet.

Comparisons Regarding RHA Milk Production. The NRCS model does not include milk production in its calculations. This makes it insensitive to differences

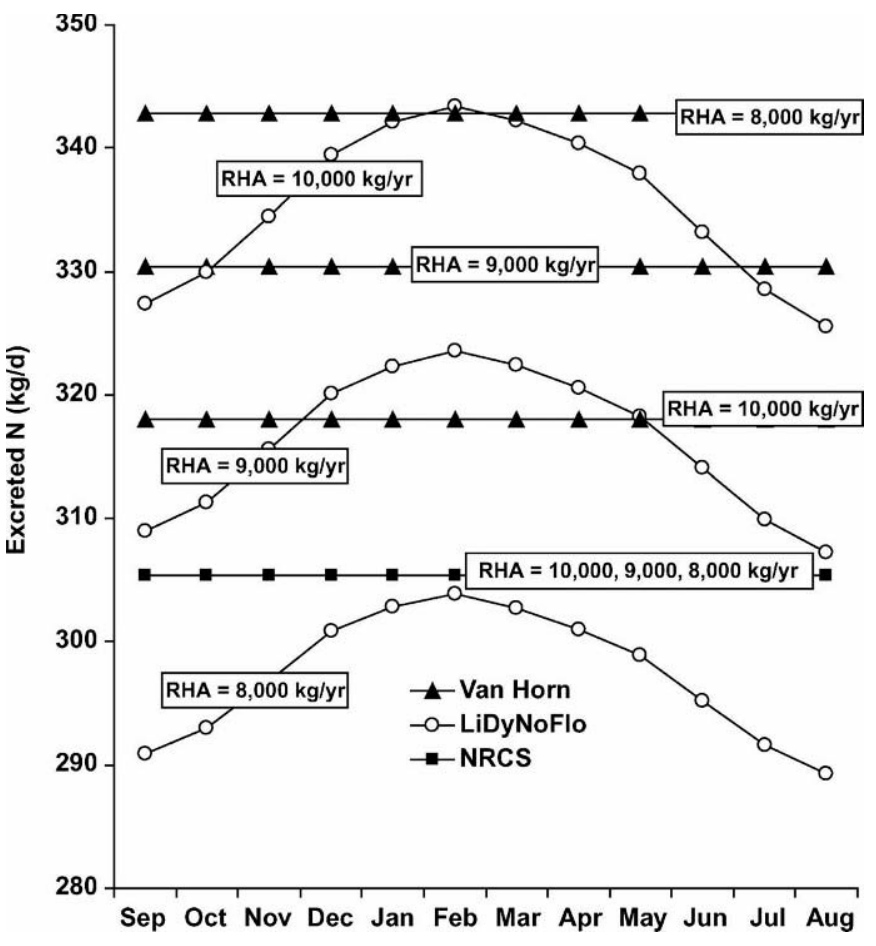

Figure 4. Nitrogen excretion by a hypothetical 1,000-cow dairy farm in north Florida for different rolling herd average (RHA) milk production measured in kilograms per year per cow as simulated by different models: Van Horn, Natural Resource and Conservation Service (NRCS), and the Livestock Dynamic North Florida (LiDyNoFlo).

in milk RHA. The $\mathrm{N}$ excretion estimates of the NRCS model were fixed at $305 \mathrm{~kg} / \mathrm{d}$ or 111.5 tonne/yr and would correspond approximately to a RHA of $8,500 \mathrm{~kg}$ of milk/yr per cow with the LiDyNoFlo. The LiDyNoFlo and Van Horn model have opposite impacts on N excretion as related to RHA. In the LiDyNoFlo, increased milk production drives an increase in DMI that (at similar amounts of $\mathrm{CP}$ ) leads to an increase in $\mathrm{N}$ intake. Because of inefficiencies, this increase in $\mathrm{N}$ intake leads to a concomitant increase in $\mathrm{N}$ excretion. Dry matter intake is an independent input in the Van Horn model, and it was assumed to remain constant in this comparison. Consequently, whereas the LiDyNoFlo predicts greater amounts of $\mathrm{N}$ excreted with a greater RHA, the Van Horn model predicts lesser amounts of $\mathrm{N}$ excretion with a greater RHA (Figure 4).

When the RHA was assumed to be $10,000 \mathrm{~kg}$ of milk/ yr per cow, the LiDyNoFlo predicted an increase in $\mathrm{N}$ excretion of $5.5 \%$ (from 116.0 to 122.4 tonne/yr) with respect to the default RHA of $9,000 \mathrm{~kg}$ of milk/yr per cow. The same change in RHA for the Van Horn model showed a decrease of $\mathrm{N}$ excretion of $3.8 \%$ (from 120.6 to 116.1 tonne/yr). With a RHA of $10,000 \mathrm{~kg}$ of milk/yr per cow, the overall yearly LiDyNoFlo estimates were 
$105.5 \%$ of the Van Horn model, varying from the RHA of $9,000 \mathrm{~kg} / \mathrm{yr}$ per cow when they were $96.2 \%$.

When the RHA was changed to $8,000 \mathrm{~kg}$ of milk/yr per cow, the LiDyNoFlo predicted a decrease in the $\mathrm{N}$ excretion of $6.5 \%$ (from 116.0 to 108.5 tonne/yr) compared with the default RHA of $9,000 \mathrm{~kg}$ of milk/yr per cow. When this change was applied to the Van Horn model, the $\mathrm{N}$ excretion increased in the same proportion as previously, $3.8 \%$ (from 120.6 to 125.1 tonne/yr). With a RHA of $8,000 \mathrm{~kg}$ of milk/yr per cow, the overall yearly LiDyNoFlo calculations represented $86.7 \%$ of the Van Horn model. The prediction curves of $\mathrm{N}$ excretion with the LiDyNoFlo follow the same seasonal pattern throughout the year. Assuming a RHA of 8,000, 9,000, and $10,000 \mathrm{~kg}$ of milk/yr per cow, the maximums were found in February $(304,323$, and $343 \mathrm{~kg}$ of N/d), and the minimums were found in August (289, 307, and 326 $\mathrm{kg}$ of N/d). For the same RHA, the Van Horn model predicted 343,330 , and $318 \mathrm{~kg}$ of N/d for any month of the year.

Comparisons Regarding Quantity of Mature Bulls. The NRCS and Van Horn models do not consider $\mathrm{N}$ excretion from mature bulls. Consequently, the $\mathrm{N}$ excretion estimates are insensitive to the inclusion of mature bulls in the dairy farm system. Figure 5A shows the inclusion of 5 and $10 \%$ (of the total number of cows) of mature bulls.

According to LiDyNoFlo, every additional bull increased the $\mathrm{N}$ excreted by $0.16 \mathrm{~kg} / \mathrm{d}$. The increased amount by 50 bulls was $3,013 \mathrm{~kg}$ of N/yr, and the increased amount by 100 bulls was $6,027 \mathrm{~kg}$ of N/yr. These quantities represent a 2.6 and $5.2 \%$ increase in the overall $\mathrm{N}$ excretion in a 1,000-cow dairy farm. Seasonality in the estimates was unaffected by inclusion of mature bulls.

Comparisons Regarding Percentage of Heifers Raised. The Van Horn model is insensitive to the inclusion of heifers in the predictions of $\mathrm{N}$ excreted. Figure $5 \mathrm{~B}$ shows the predicted amounts of $\mathrm{N}$ excreted in the farm when 0,50 , or $100 \%$ of heifers are raised on farm. The predicted $\mathrm{N}$ excreted by LiDyNoFlo and the NRCS model increased by 9.7 and 10.3 tonne/yr for $50 \%$ of heifers raised and 19.5 and 20.7 tonne/yr for $100 \%$ of heifers raised, respectively. The overall $\mathrm{N}$ excretion in the farm increased by 8.4 and $9.3 \%$ by raising $50 \%$ of heifers, and it increased 16.8 and $18.5 \%$ by raising $100 \%$ of heifers in the LiDyNoFlo and NRCS model, respectively.

Comparisons Regarding Seasonality of Operation. Only LiDyNoFlo is sensitive to seasonality of production. Using this model, it was found that overall $\mathrm{N}$ excretion per year decreased only slightly $(<0.5 \%$, from 116 to 115.6 and to 115.5 tonne/yr) when the farm decreased seasonality from the default value of $100 \%$ to
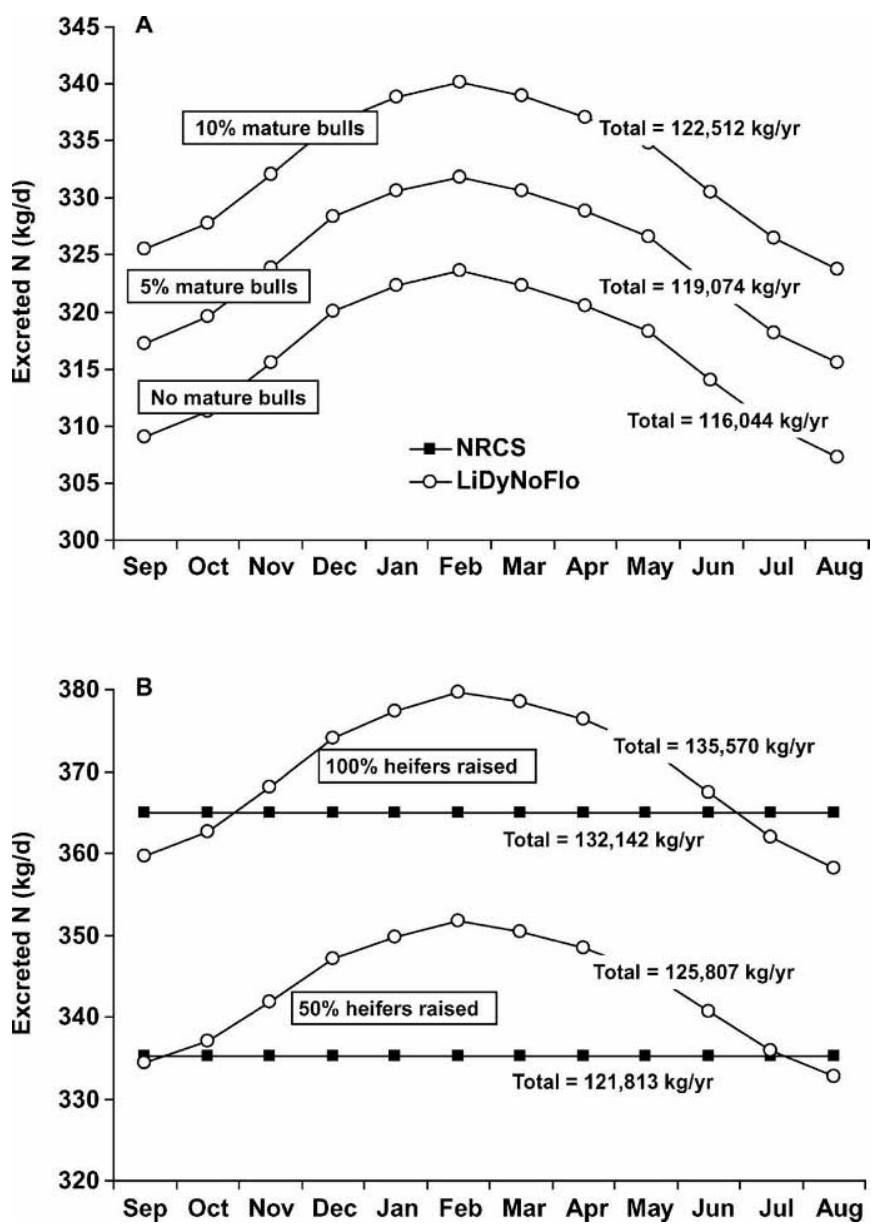

Figure 5. Nitrogen excretion $(\mathrm{kg} / \mathrm{d})$ by a hypothetical $1,000-\mathrm{cow}$ dairy farm in north Florida for different proportions of mature bulls (A) and different percentages of heifers raised on farm (B) as simulated by different models: Natural Resource and Conservation Service (NRCS), and the Livestock Dynamic North Florida (LiDyNoFlo).

50 and $0 \%$. Major changes occurred, however, in the patterns of $\mathrm{N}$ excretion throughout the year.

This seasonality predicted maximum $\mathrm{N}$ excreted by heifers in January (28 and $56 \mathrm{~kg} / \mathrm{d}$ for 50 and $100 \%$ of heifers raised, respectively) and the minimum $\mathrm{N}$ excreted by heifers in September (25 and $50 \mathrm{~kg} / \mathrm{d}$ for 50 and $100 \%$ of heifers raised, respectively). This seasonality predicted by LiDyNoFlo for the $\mathrm{N}$ excretion of heifers varied less throughout the year and shows different patterns from the $\mathrm{N}$ excreted by cows (Figure 6B).

When seasonality decreased, $\mathrm{N}$ excretion also decreased during winter and increased during summer, making the $\mathrm{N}$ excretion curve flatter (at $50 \%$ of seasonality) and completely flat (at $0 \%$ seasonality) throughout the year (Figure $6 \mathrm{~A}$ ). At $0 \%$ seasonality, the other 2 model predictions were parallel with LiDyNoFlo. The LiDyNoFlo curve was intermediate. The $\mathrm{N}$ excretion with different seasonality was always in between pre- 

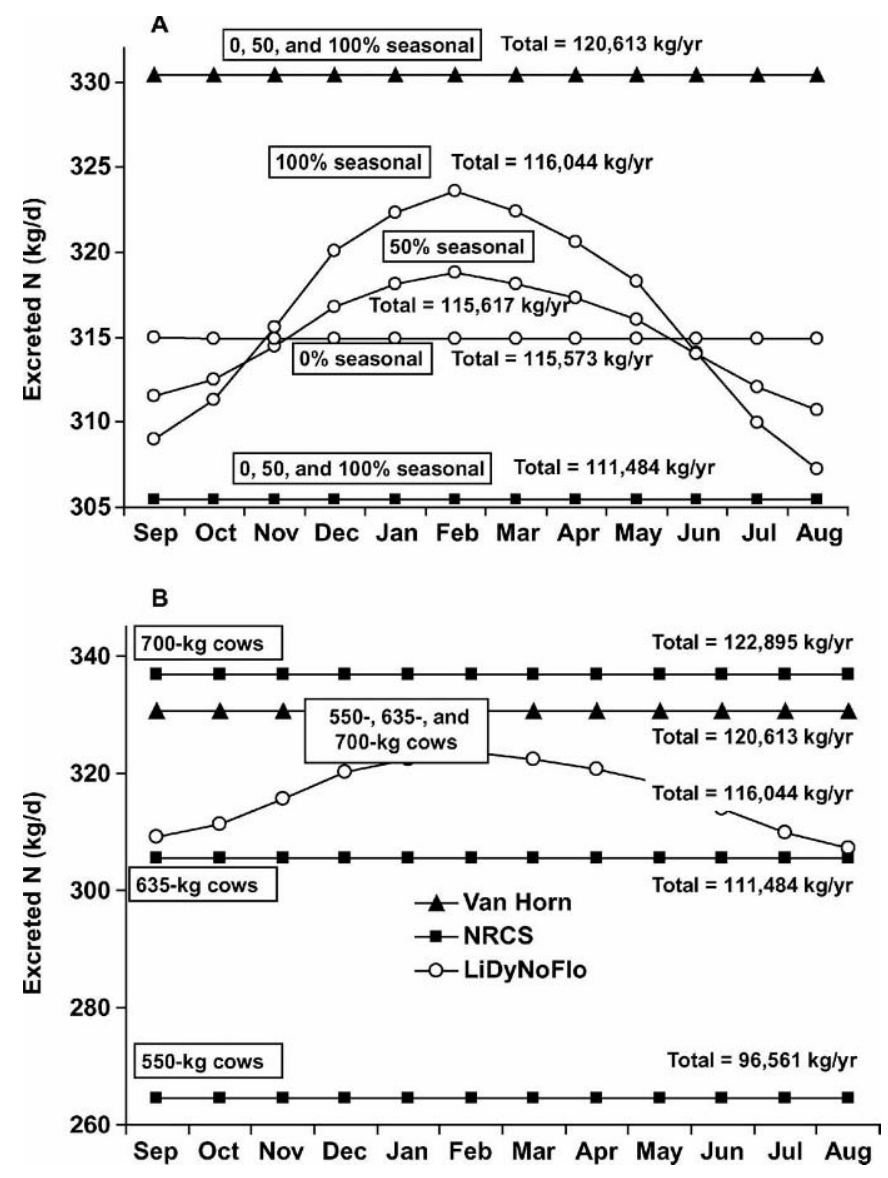

Figure 6. Nitrogen excretion by a hypothetical 1,000-cow dairy farm in north Florida for different seasonality levels (A) and for different cow weights (B) as simulated by different models: Van Horn, Natural Resource and Conservation Service (NRCS), and the Livestock Dynamic North Florida (LiDyNoFlo).

dictions of the NRCS (115.9 tonne/yr) and Van Horn (119.6 tonne/yr) models.

Comparisons Regarding BW of Cows. Only estimates of $\mathrm{N}$ excretion from the NRCS model are sensitive to BW of cows. The LiDyNoFlo and the Van Horn model do not include a component of BW in their predictions. Figure 6B shows the variation in $\mathrm{N}$ excreted when cows weigh 550, 635 (default), and $700 \mathrm{~kg}$ each. The NRCS model is highly sensitive to this factor. In the NRCS model, $1 \mathrm{~kg}$ of BW of a milking cow contributes $0.48 \mathrm{~g}$ of $\mathrm{N}$ excreted. The $\mathrm{N}$ excretion increased $10.2 \%$ (from 111.5 to 122.9 tonne/yr) for the same proportion of increase in BW (from 635 to $700 \mathrm{~kg}$ ) and decreased $13.4 \%$ (from 111.5 to 96.6 tonne/yr) for the same proportion of change in BW (from 635 to $550 \mathrm{~kg}$ ).

\section{DISCUSSION}

Models that predict total $\mathrm{N}$ excretion at the dairy farm level are difficult to validate with observed data because there are no field studies of total $\mathrm{N}$ excretion at the dairy farm level. Typically, measurements from individual animals are extrapolated to the farm level and are used to parameterize models such as the NRCS and Van Horn models. The LiDyNoFlo also takes advantage of these measurements to parameterize its calculations, but it goes beyond the scope of previous models by including probabilistic simulation of cow flow and milk production to predict the total $\mathrm{N}$ excreted. Unlike previous approaches, cow states in the LiDyNoFlo are disaggregated into thousands of potential categories for which calculations are performed individually. The LiDyNoFlo is strongly supported with a detailed description of its components. Predictions of total N excretion from LiDyNoFlo were consistently between the Van Horn model (upper end) and the NRCS model (lower end).

We compared predictions of $\mathrm{N}$ excretion by individual animals using LiDyNoFlo with published data (Table 3 ). For a cow producing $40 \mathrm{~kg}$ of milk/d, the estimates from LiDyNoFlo and from Nennich et al. (2003) were equal, $0.45 \mathrm{~kg}$ of $\mathrm{N} / \mathrm{d}$, whereas estimates of Wilkerson et al. (1997) were $0.41 \mathrm{~kg} / \mathrm{d}$. For a cow producing $30 \mathrm{~kg}$ of milk/d, the estimates from LiDyNoFlo and Wilkerson et al. (1997) were equal, $0.35 \mathrm{~kg} / \mathrm{d}$, whereas estimates by Nennich et al. (2003) were $0.41 \mathrm{~kg} / \mathrm{d}$. For a cow producing $20 \mathrm{~kg}$ of milk/d, the estimates from LiDyNoFlo and Wilkerson et al. (1997) were equal, $0.28 \mathrm{~kg}$ of $\mathrm{N}$ excreted/d, whereas estimates of Nennich et al. (2003) were $0.37 \mathrm{~kg}$ of $\mathrm{N}$ excreted/d.

Jonker et al. (1998) reported $\mathrm{N}$ excretion by milking cows of $0.43 \mathrm{~kg} / \mathrm{d}$, and Jonker et al. (2002) reported such as $0.38 \mathrm{~kg} / \mathrm{d}$; the overall average of lactating cows using LiDyNoFlo was $0.36 \mathrm{~kg} / \mathrm{d}$.

The 2003 ASAE standard indicates that $0.29 \mathrm{~kg}$ of N is excreted/d per cow (ASAE, 2003), which corresponds to cows milking $22.01 \mathrm{~kg} / \mathrm{d}$ with LiDyNoFlo, $21.48 \mathrm{~kg} /$ $\mathrm{d}$ with the Wilkerson et al. (1997) model, and $1.6 \mathrm{~kg} / \mathrm{d}$ with the Nennich et al. (2003) model.

The Van Horn model predicts N excretion of $0.34 \mathrm{~kg} /$ $\mathrm{d}$ for lactating cows and $0.28 \mathrm{~kg} / \mathrm{d}$ for dry cows. The NRCS model predicts N excretion of $0.32 \mathrm{~kg} / \mathrm{d}$ for lactating cows, $0.20 \mathrm{~kg} / \mathrm{d}$ for dry cows, and $0.11 \mathrm{~kg} / \mathrm{d}$ for heifers. Estimates from the 3 compared models fall within the literature estimates.

The direct effect of $\mathrm{BW}$ on $\mathrm{N}$ excretion for lactating cows was not included in LiDyNoFlo. Per-cow estimates of $\mathrm{N}$ excretion with standard BW $(635 \mathrm{~kg})$, however, were not different from published data (shown previously). The LiDyNoFlo has a solid structure of cow flow and milk production over time. Further refinements, such as adding the direct effect of BW on $\mathrm{N}$ excretion, could be easily included. 
Different ways exist for milk production to impact $\mathrm{N}$ excretion among the 3 models. According to the Van Horn model, the greater the milk production, the greater the amount of $\mathrm{N}$ exported with that milk, and therefore, the less $\mathrm{N}$ excreted (DMI is assumed to remain constant). Using LiDyNoFlo, increased milk production is associated with increased DMI and, therefore, increased $\mathrm{CP}$ and $\mathrm{N}$ intake. Because of inefficiencies, this increase in $\mathrm{N}$ intake leads to a concomitant increase in $\mathrm{N}$ excretion (Wilkerson et al., 1997; Nennich et al., 2003). Jonker et al. (1998) integrated $\mathrm{N}$ intake and milk $\mathrm{N}$ to predict $\mathrm{N}$ excretion in a nutrient balance: $\mathrm{N}$ excreted $=\mathrm{N}$ intake $-\mathrm{N}$ in milk produced (assuming body maintenance is negligible). Consequently, at a constant DMI, the effect of increased milk production will decrease the $\mathrm{N}$ excreted. This is not a very realistic situation because increased milk production will usually be achieved via increased DMI. The LiDyNoFlo has another approach: DMI and N excretion are functions of milk production in each cow state (Nennich et al., 2005). Consequently, the effect of increased milk production will be increased DMI, which because of inefficiencies, will lead to greater amounts of $\mathrm{N}$ excretion.

Amounts of $\mathrm{N}$ excretion by mature bulls and heifers are important in whole dairy farm accountability of $\mathrm{N}$, and they should not be disregarded. The LiDyNoFlo allows for including both mature bulls and heifers. The effect of $10 \%$ (of total cows) of bulls increased the amount of $\mathrm{N}$ excretion by $18 \mathrm{~kg}$ of N/d or $6,570 \mathrm{~kg}$ of N/yr. The effect of raising heifers, using LiDyNoFlo, increased the amount of $\mathrm{N}$ excretion by $55 \mathrm{~kg}$ of N/d or $20,075 \mathrm{~kg}$ of N/yr. Exclusion of heifers and bulls may underestimate total farm $\mathrm{N}$ excretion by $18 \%$.

Because of seasonal climatic changes, seasonality in production occurs naturally and should be accounted for because it impacts $\mathrm{N}$ excretion over time. The LiDyNoFlo is the only model that accounts for this seasonality in $\mathrm{N}$ excretion. A case of $100 \%$ seasonality is the closest to real conditions, when peak milk production (Figure 2) and peak N excretion occur in February (Figure 3 ).

The LiDyNoFlo is a combination of complexity and functionality in a model that reflects major critical characteristics of farms such as dynamic cow flow and milk production with end-user friendliness. It is a practical tool for producers, consultants, and policy makers. The LiDyNoFlo takes advantage of the simplicity of previous approaches (Van Horn and NRCS) and a new body of literature that demonstrates that milk production is the major predictor of $\mathrm{N}$ excretion (Nennich et al., 2003).

Total $\mathrm{N}$ excretion on dairy farms impacts total $\mathrm{N}$ losses from the farm, and consequently, this affects ground and surface water quality. Predictions of $\mathrm{N}$ ex- cretion at the farm scale are the first step to understand and evaluate environmental impacts.

The LiDyNoFlo has been integrated with crop growth and decision models to propose management strategies that would be economically feasible and environmentally sustainable, as shown in Cabrera et al. (2005). The innovative seasonality component of LiDyNoFlo makes that integration possible. The main means of recycling excreted $\mathrm{N}$ is through fertilization of crops. Opportunity to use this excreted $\mathrm{N}$ is highly dependent on field crops, which are seasonal. For example, greater risks of $\mathrm{N}$ loss exist during winter because, during this season, there is greater $\mathrm{N}$ excretion and less crop $\mathrm{N}$ demand. In addition, the seasonal structure of the LiDyNoFlo allows accounting for interannual seasonal climate variability for anticipating management strategies according to climate forecasts as in the case of El Niño, Neutral, or La Niña years (Cabrera et al., accepted). In addition, by using the structure of the LiDyNoFlo, it is possible to simulate changes in herd size over time and evaluate their environmental consequences.

\section{CONCLUSIONS}

A user-friendly model that accurately estimates seasonal $\mathrm{N}$ excretion on north Florida dairy farms was developed, the LiDyNoFlo. The LiDyNoFlo estimates total farm $\mathrm{N}$ excretion per month of year. In contrast to the other $2 \mathrm{~N}$ excretion models widely used in Florida (NRCS, 2001; Van Horn et al., 2001), the LiDyNoFlo accounts for dynamic cow flow and seasonality of operation. On a per-cow basis, predictions of the LiDyNoFlo were very close to others (Wilkerson et al., 1997; Nennich et al., 2003). Comparisons of the LiDyNoFlo predictions with the other 2 models showed differences between 3 and 10\%. The LiDyNoFlo consistently predicted in between the Van Horn (upper end) and the NRCS (lower end) models. Further research should be undertaken to verify LiDyNoFlo predictions with field data. Additional refinements of the LiDyNoFlo should include additional variables such as BW and independent amounts of CP by cow states.

\section{REFERENCES}

Albert, M. 2002. Monitoring and modeling the fate and transport of nitrate in the vadose zone beneath a Suwannee River basin vegetable farm. M.S. Thesis, Univ. Florida, Gainesville.

American Society of Agriculture Engineers. 2003. Manure production and characteristics. ASAE Standards D384.1. ASAE, St. Joseph, MI.

Andrew, W. J. 1994. Nitrate in ground water and spring water near four dairy farms in North Florida 1990-1993. Water-Resources Investigations Rep. 94-4162. U.S. Geological Survey, Tallahassee, FL. 
Berndt, M. P., H. H. Hatzell, C. A. Crabdall, M. Turtora, J. R. Pitman, and E. T. Oaksbord. 1998. Water quality in the Georgia-Florida coastal plain, Georgia and Florida, 1992-1996. Circ. 1151. U.S. Geological Survey, Reston, VA.

Cabrera, V. E. 2004. Modeling North Florida dairy farm management strategies to alleviate ecological impacts under varying climatic conditions: An interdisciplinary approach. Ph.D. Diss., Univ. Florida, Gainesville.

Cabrera, V. E., N. E. Breuer, P. E. Hildebrand, and D. Letson. 2005. The dynamic north-Florida dairy farm model: A user-friendly computerized tool for increasing profits while minimizing environmental impacts. Comput. Electron. Agric. 49:286-308.

Cabrera, V. E., P. E. Hildebrand, J. W. Jones, D. Letson, and A. de Vries. 2006. An integrated North Florida dairy farm model to reduce environmental impacts under seasonal climate variability. Agric. Ecosyst. Environ. 113:82-97.

de Vries, A. 2004. Economic value of delayed replacement when cow performance is seasonal. J. Dairy Sci. 87:2947-2958.

de Vries, A., and C. A. Risco. 2005. Trends and seasonality of reproductive performance in Florida and Georgia herds from 1976 to 2002. J. Dairy Sci. 88:3155-3165.

Fraisse, C. W., K. L. Campbell, and J. W. Jones, and W G. Boggess. 1996. GIDM: A GIS-based model for dairy waste management analysis. Proc. Am. Water Resource Assoc. Symp. on GIS and Water Resources, Ft. Lauderdale, FL. Available: http://awra.org/ proceedings/gis32/fraisse/ Accessed June 18, 2004.

Jalvingh, A. W., A. A. Dijkhuizen, and J. A. M. Van Arendonk. 1994. Optimizing the herd calving pattern with linear programming and dynamic probabilistic simulation. J. Dairy Sci. 77:1719-1730.

Jonker, J. S., R. A. Kohn, and R. A. Erdman. 1998. Using milk urea nitrogen to predict nitrogen excretion and utilization efficiency in lactating dairy cows. J. Dairy Sci. 81:2681-2692.

Jonker, J. S., R. A. Kohn, and J. High. 2002. Dairy herd management practices that impact nitrogen utilization efficiency. J. Dairy Sci. 85:1218-1226.

Katz, B. G., and R. S. de Han. 1996. The Suwannee River basin pilot study: Issues for watershed management in Florida. Fact Sheet FS-080-96. U.S. Geological Survey, Reston, VA.

Katz, B., D. Hornsby, F. Bohlke, and M. Mokray. 1999. Sources and chronology of nitrate contamination in spring waters, Suwannee River Basin, Florida. Water-Resources Investigations Rep. 994252. U.S. Geological Survey, Tallahassee, FL.

NRC. 2001. Nutrient Requirement of Dairy Cattle. 7th ed. Natl. Acad. Sci., Washington, DC.

Natural Research and Conservation Service. 2001. Water Budget and Nutrient Balance Worksheet, WATNUTFL Version 2.0. Part 650. Engineering Field Handbook. 210-VI-EFH. NRCS, Gainesville, FL.
Nennich, T., J. H. Harrison, D. Meyer, W. P. Weiss, A. J. Heinrichs, R. L. Kincaid, W. J. Powers, R. K. Koelsch, and P. E. Wright. 2003. Development of standard methods of estimate manure production and nutrient characteristics from dairy cattle. Pages 263-268 in Proc. 9th Int. Symp. Anim., Agric. Food Processing Wastes, Raleigh, NC.

Nennich, T., J. H. Harrison, L. M. VanWieringen, D. Meyer, A. J. Heinrichs, W. P. Weiss, N. R. St-Pierre, R. L. Kincaid, D. L. Davidson, and P. E. Wright. 2005. Prediction of manure and nutrient excretion from dairy cattle. J. Dairy Sci. 88:3721-3733.

Pitman, J. R., H. H. Hatzell, and E. T. Oaksford. 1997. Spring contributions to water quantity and nitrate loads in the Suwannee River during base flow in July 1995. Water-Resources Investigations Rep. 97-4152. U.S. Geological Survey, Tallahassee, FL.

St-Pierre, N. R., and L. R. Jones. 2001. Forecasting herd structure and milk production for production risk management. J. Dairy Sci. 84:1805-1813.

USDA. 1992a. Agricultural Waste Management Field Handbook, Chapter 4: Agricultural Waste Characteristics. 210-VI-NEH651.04. Soil Conservation Service, Washington, DC.

USDA. 1992b. Agricultural Waste Management Field Handbook, Chapter 4: Agricultural Waste Characteristics. 210-VI-NEH651.04. Amendment FL-9, FL651.1004(f). Soil Conservation Service, Tallahassee, FL.

USDA. 1992c. Agricultural Waste Management Field Handbook, Chapter 6: Role of Plants in Waste Management. 210-VI-NEH651.06. Soil Conservation Service, Washington, DC.

Van Horn, H. H., G. L. Newton, G. Kidder, E. C. French, and R. A. Nordstedt. 2001. Managing dairy manure accountability: Worksheets for nutrient budgeting. Coop. Ext. Serv. Circ. 1196. Univ. Florida, Gainesville.

Van Horn, H. H., G. L. Newton, R. A. Nordstedt, E. C. French, G. Kidder, D. A. Graetz, and C. F. Chambliss. 1998. Dairy manure management: Strategies for recycling nutrients for recover fertilizer value and avoid environmental pollution. Coop. Ext. Serv. Circ. 1091. Univ. Florida, Gainesville.

Van Horn. H. H., R. A. Nordstedt, A. V. Bottcher, E. A. Hanlon, D. A. Graetz, and C. F. Chambliss. 1991. Dairy manure management: Strategies for recycling nutrients to recover fertilizer value and avoid environmental pollution. Coop. Ext. Serv. Circ. 1016. Univ. Florida, Gainesville, FL.

Van Horn, H. H., A. C. Wilkie, W. J. Powers, and R. A. Nordstedt. 1994. Components of dairy manure management systems. J. Dairy Sci. 77:2008-2030.

West, J. W., B. G. Mullinix, and J. K. Bernard. 2003. Effects of hot, humid weather on milk temperature, dry matter intake, and milk yield of lactating dairy cows. J. Dairy Sci. 86:232-242.

Wilkerson, V. A., D. R. Mertens, and D. P. Casper. 1997. Prediction of excretion of manure and nitrogen by Holstein dairy cattle. J. Dairy Sci. 80:3193-3204. 